\title{
A Novel Experience in Crime Narrative: Watching and Reading The Killing
}

\author{
NEIL ARCHER*
}

\begin{abstract}
This essay will consider the adaptation of series one of the Danish television serial Forbrydelsen/The Killing (2007) into David Hewson's novel The Killing (2012). Considering the television show through theoretical paradigms of contemporary long-form television, I will examine the discourses of 'the novel' and the 'novelistic' as they relate to both texts. As I will argue, attributing 'novelistic' characteristics to television texts may be problematic, but it also provides a significant opportunity for rethinking dominant or fixed conceptions of the novel as a cultural form and product. Looking closely at Hewson's novel, the paper will also aim to reconfigure the 'convergence' model of novelization, thinking instead about the novel adaptation as a form of interpretive process across media. In doing this, I will consider how such adaptations are informed by conceptions of novelistic form and style, which may work discursively to reconfigure or 'legitimize' the adapted text but also to disavow 'low' cultural connotations.
\end{abstract}

Keywords Forbrydelsen, The Killing, novelization, novel, Nordic noir, long-form television.

Perhaps entirely obviously, the title of this paper alludes to two different meanings of the word 'novel'. This play on words is motivated by the two texts that are the focus of this essay: the first series of the television show Forbrydelsen, made in 2007 by the Danish public service broadcaster DR, screened in the United Kingdom in 2011 as The Killing; and the novel by David Hewson, also called The Killing, published by Pan Macmillan in 2012. ${ }^{1}$ In choosing to look at a piece of original screen media turned into a book, I am looking at what constitutes a rare, or indeed novel, movement of adaptation within crime narrative fiction more generally. Novels and short stories of crime and detection have long been a staple resource of television adaptation, through the stories of Arthur Conan Doyle, Agatha Christie, and Georges Simenon to those more recent works by writers such as P.D. James, Ruth Rendell, Colin Dexter, and Henning Mankell, to name but a select few. It is nevertheless unusual to see original crime screenwriting adapted into novels; furthermore, while the film novelization has more of a recognised tradition, this tradition has rarely been synonymous with the 'literary' qualities that, I will argue here, are inherent to both the marketing and form of Hewson's The Killing.

The apparently narrow focus of my argument is therefore determined as much by the limitations of the field of study as it is by parameters of this essay. As I will argue, though, the novelization of The Killing is not so much unique as a nuanced variant on the wider practices of adaptation within which it is situated. What makes The Killing both distinct and significant is that it emphasizes the increased cultural evaluation and

*Faculty of Humanities, Keele University. E-mail:n.archer@keele.ac.uk. 
shifting critical prominence of the television serial as a media form. In the absence of other comparative novelizations, then, I at least hope to shed some reflective light on the other televisual texts I will be referring to here alongside Forbrydelsen. ${ }^{2}$

Above all, I am interested in what, across and between these two texts, may inform our view of what we mean by 'the novel' or the 'novelistic'. As I will discuss, both the 'long-form' narrative approach of Forbrydelsen and the stylistic strategies of Hewson's adaptation lend themselves to discussion within the terms of the novel as an artistic form. This would in itself suggest that 'the novelistic' as a discursive category is not reducible to any particular textual medium, but at the same time, this would also imply that the connotations of 'the novel' are increasingly shaped by certain evaluations of form, and perhaps also of taste. This essay aims then to think beyond the onedirectional movement of adaptation, considering the discourse of the novel as it relates to both television and literary form and locating these discussions within evolving, transmedia conceptions of 'literary' culture. As I will argue, just as the adaptation of prose fiction into screen media can reflect different historical readings of, and relationships to, literary works, so can choices in approach to novelization reflect changing attitudes towards film and television narratives.

\section{RETHINKING THE NOVELIZATION}

As Hewson's book is technically a novelization, it is worth thinking briefly about the implications of this particular term. As hardly needs noting, the adaptation from novel into film or television has become an accepted area both of industry practice and academic study. The middlebrow contexts within which such adaptations are frequently consumed, moreover - niche cinematic distribution and prestige television slotsindicate the discursive respectability of screen adaptations. Indeed, as Jim Collins has shown, the literary adaptation in recent years has actually redefined what we understand by 'literary' itself. Collins' point is that the television and (especially) film adaptation, within the 'increasing convergence of literary and visual cultures' in the contemporary cultural marketplace, has established an interdependency across and between media: this 'cine-bibliophilia', as Collins calls it, 'suggest[s] profound changes in the relative status of both reading and watching' (Bring on the Books 120).

Within what Henry Jenkins has called 'convergence culture', the literary source text for adaptation is refunctioned: no longer the ultimate source of authority, it becomes a form of parallel experience, a reiteration of the 'cine-literary' values (Collins, Books 122) already established by the particular aesthetics, production values, and discursive positioning of the screen adaptations. Collins is particularly attentive to the way that the so-called 'tie-in' editions of adapted literature are frequently marketed through the imagery of the films they inspired (Bring on the Books 120-121), as if the literature actually partakes of the same material from which the film/television show is made. Novelizations, and Hewson's is no exception, share these same paratextual motifs as the tie-in novel, but what else do they share? Collins' argument is shaped by its nuanced understanding of how discursive values of the 'literary' have come to dominate middlebrow, even popular, culture in a transmedia synergistic fashion, yet the hyphenated, hybridized categories he sees emerging from this culture are still dominated by an idea of the literary, one still predicated on the idea of great authors and their works. Focusing 
on the same kinds of adaptations that Collins studies, Simone Murray has identified the way that 'cultural hierarchies', in this instance the primacy of the literary text, are paradoxically 'kept alive by the same [trans-media] industry that pushes audiences to consume near-identical content across multiple media platforms' (11).

Collins consequently does not look at novelizations, probably because they do not fit so clearly within his discussion, but more obviously because, at least hitherto, they have tended to be positioned at the margins of literary evaluation. While both novelization and adapted novel can share tie-in status at the level of marketing, the adapted novel can always justify its existence beyond the terms of commodification. As novelization theorist Jan Baetens also points out, this commercially contingent nature of novelizations has proved a barrier to their critical respectability, along with the fact that many authors of novelizations are either freelance writers-for-hire or more established writers working under a pseudonym (227).

Baetens' interesting take on the novelization is that, in its structural closeness to its source text (resulting from the fact that novelizations are frequently adapted from screenplays), the medium is a kind of 'anti-adaptation' (234). Yet, as this essay will argue, this apparent redundancy, its excessive proximity to its textual origin, tends to beg the question of a novelization's very existence: if it serves no purpose, as the logic of redundancy would suggest, what motivates its readers? Because of the general disparity between scales of film/television viewing and novel reading, buying or borrowing a novelization would logically represent a decision to read fiction on the part of the viewer. This is why John Ellis has it slightly wrong when he describes film and television adaptation as 'prolonging the pleasure of the original representation ... repeating the production of a memory' (4), as this would seem to make more sense in the case of the novelization. Moreover, given the low evaluative status of the novelization, this logic would suggest the novelization responds to the interpretive intent of viewers/readers to experience visual texts through some framework of novelistic perception. Murray has nevertheless called for a more cautious and sceptical approach, balancing the recognition of audience/reader practices with an awareness of the 'production contexts, financial structures, and legal regimes' (7) underpinning what she calls the 'adaptation industry'.

Hewson's novel is indeed 'legitimated', both by its legally approved status and its acknowledged fidelity to the television show's narrative (the cover of the paperback version describes it as a novel 'based on the original screenplay', and features an image of Forbrydelsen's star, Sophie Gråbøl, who plays the show's detective Sarah Lund). As I will discuss here, even within the terms of the supposedly narrow semiotic gap between novelizations and their sources (Baetens 234), Hewson's novel can be read as a form of interpretation and even critical reading of the television series, one informed by specific evaluative and aesthetic paradigms. Taking my lead from both Collins and Murray, though, I will also consider the ways in which Forbrydelsen and The Killing represent between them a significant example of contemporary media's mutually informing tendencies and, in particular, their combined textual construction of a type of literary value. But what makes this particular conjunction of products distinctive, even novel, is that in this case such value, even if it does discursively position the literary as dominant, does not do so by reference to a prior literary text per se, but rather to a television show. 
I will therefore oppose Baetens' argument that the novelization mostly exemplifies our contemporary tendency toward 'global ... cross-media packag[ing]' (235). Baetens refers to, though ultimately resists, Jay Bolter and Richard Grusin's influential theory of 'remediation' as a way of reading novelizations, on the grounds that as a form the latter is too old-fashioned, and too uninterested in rethinking representation, to fit with Bolter and Grusin's focus on new media's appropriations and revisions. Hence, Baetens argues, the novelization does away with the binary model of adaptation altogether, embodying instead convergence culture's drive towards 'multiplication [and] infinite reduplication' (236). This argument might be persuasive with regard to the novelization generally, especially in the contexts of twenty-first-century cultural production, where the literary, filmic, and televisual franchise is dominant. But within these terms, the specificity of The Killing still needs to be addressed. The cold logic of convergence does not in itself explain the specific forms of cine-literary culture and the persistence of certain ideas of literary value and taste. In terms of the present essay, then, what is it that motivated the novelization of this particular show and what can this tell us about contemporary conceptions of televisual and literary value?

For one thing, we need to be attentive to the wider discursive positioning of Scandinavian crime narratives in the international television and bookselling contexts. The wider global pre-eminence of so-called 'Nordic noir', at least within the parameters of foreign-language literature and screen media, is both accounted for and attested to by Barry Forshaw's book on the subject, which makes reference to the 'novelty and perceived "quality" (1) of Forbrydelsen in its opening paragraphs. Notions of 'novelty' and 'quality' within the perhaps overdetermined contexts of translated prose fiction and subtitled television explains to some extent the type of cultural value accruing to both Forbrydelsen and its novel adaptation. I first came across Hewson's novel on a display table in my local branch of Waterstones, the most prominent bookstore in the United Kingdom, its status as a novelization occluded by its positioning alongside other examples of 'original' Scandinavian crime fiction. Forshaw's attention to the demands of publishing houses to find 'the Next Big Name in Scandinavian crime fiction' (2) echoes Murray's point that the novel, once held as the unique, individually crafted prime mover within adaptation study, is itself 'as much the product of institutions, agents, and material forces as is the Hollywood blockbuster' (8), and indeed, Scandinavian film and television production companies such as Yellow Bird have made the adaptation of novels by Henning Mankell, Stieg Larsson, and Jo Nesbø - the three most commercially prominent novelists within the Scandinavian crime fiction industry - their industrial signature (Archer 5), suggesting a close alliance of literary and screen output. In the same way that Forshaw situates Forbrydelsen within the broader, mainly literary contexts of Nordic noir, we must remain attuned to the status of both Forbrydelsen and The Killing as part of contemporary narrative media's 'merchandized collective experience' (Baetens 235). But we should also recognize the particular, mutually informing circuits of publicity for both Scandinavian screen adaptations and novels, whether these be the niche-marketed, quality-bookstore associations of a Waterstones or the way that, in the United Kingdom, distributors of Nordic film and publishers of Nordic crime novels are strategically targeting train commuters - presumably seen as the most conspicuous regular consumers of fiction - in the promotion of their properties (Archer 7). ${ }^{3}$ 
Reading The Killing within the logic of remediation, and not just through the logic of convergence or merchandizing, still has some currency, then, though in slightly nuanced terms to those presented by Bolter and Grusin. While we may move beyond the economy of 'loss' and 'gain' that has weighed down much adaptation discourse, binding it within the uni-linear logic of origin and authority, we may still conceive of the act of novelization through the terms of 'the novel' as a structuring interpretive framework: a persistent, and quite possibly traditional, concept of media that may be employed, not necessarily to 'improve' or 'revise' the adapted source but to legitimize it through a particular media paradigm. We may consequently see Hewson's novel, from both a writer and a reader perspective, as an experience of 'novelizing' the televisual text, which is also to read the televisual text as a sort of novel. My point here is that conceptions of the novelization as merely the rewriting of screen narrative into prose narrative may overlook the particularity of 'the novel' as a process, and even as an ontology, and not just a commercial object or simply another narrative platform among many. I will consider what constitutes this 'novel' idea and experience in what remains of this essay.

\section{'IT'S NOT TV'}

As I have implied, the idea of the 'novelistic' as a structure or mode goes both ways in this instance. Forbrydelsen's narrative in series one spans twenty-one-hour episodes, interweaving a series of separate plotlines all interconnected by one criminal act: the murder, at the start of episode one, of nineteen-year old Nanna Birk Larsen in a Copenhagen forest. Forbrydelsen is characteristic of so-called long-form television narrative, exemplified by Home Box Office (HBO) shows such as The Wire (2002-08) or The Sopranos (1999-2007), inasmuch as its narrative works accumulatively and crossreferentially across its twenty-hour duration. In these comparative terms, Forbrydelsen may be perceived within certain strains of criticism as being 'like a novel'. As both Ted Nannicelli and Jason Mittel have observed, it was The Wire - set in a fictionalized but highly detailed version of postindustrial Baltimore - that helped foster this connection, thanks both to journalistic commentary on the show, and the willingness of its writers and cast to affirm its novelistic qualities: 'As [The Wire's creator David] Simon attests in frequent interviews and commentary tracks, he is looking to tell a large sweeping story that has traditionally been the purview of the novel ... He highlights how each season offers its own structural integrity, much like a specific book within a larger epic novel, and each episode stands as a distinct chapter in that book' (Mittel 429). Nannicelli, though, argues that this claim to novelistic value inherently undermines The Wire's aesthetic ambition, as in seeking to claim kinship with the older and more traditionally respectable medium such claims signify their own reluctance to see The Wire as 'just' a television show (190-191): a reluctance, indeed, structured into HBO's production philosophy during the early 2000 s, as indicated by their former slogan 'It's not TV: it's HBO'. More importantly, Nannicelli argues, the analogy does not hold: the virtues of cross-cutting and complex narrative interweaving that have become the signature of long-form narrative television, he suggests, are products of this particular medium's development, not a debt to literature. As Mittel also argues, a realist, extended-cast show like The Wire finds no formal equivalent for the modes of focalization, internal narrative 
voice, and individual character development he identifies in the nineteenth-century novel (430), the form that is the most common reference point in these discussions.

Rather than use this to reject what we might call the novelistic fallacy in long-form television, I would like to embrace this analogy, though not on any grounds of cultural distinction or reflected value that it may usually be assumed to involve. I suggest that we preserve the novelistic analogy, in order to not only nuance the novelistic associations of recent long-form television but also think more clearly about the status, reception, and evolving form of the novel as a medium. I therefore take up a position here similar to that of Caroline Levine, who, in a response to Mittel's essay on The Wire, argues for a comparative approach based on the detailed formal and functional analysis of specific texts, rather than broader, classificatory genre-centred arguments. Such an approach encourages us to specify what we really mean when we talk about 'novelistic' television, and also what conception of the novel its producers may have in mind. In the case of Forbrydelsen/The Killing, seeing Hewson's novel as a reading of the show also encourages us to consider the kinds of discursive 'novelistic' values associated with the series and, in turn, the novel adapted from it.

Eva Novrup Redvall's account of Forbrydelsen's production history emphasizes the extent to which creator and principal screenwriter Søren Sveistrup followed the tenets of the show's producers, DR, in the emphasis on 'double storytelling': a narrative strategy involving the combination of different plots (familial, political, police-procedural), and the balancing of sociopolitical themes, within the narrative structure of a crime serial (Redvall 171-173). This 'double' strategy implies that the structures of crime narrative are in themselves not sufficient to justify the investment of a public service broadcaster, implying in turn that the series' exploration of varied social and narrative strata is the source of its depth and level of engagement. But in the case of Forbrydelsen, this discourse plays down the significantly overdetermined way it is structured by the serial form. The 'novelistic' conception of contemporary long-form television, in fact, often proves vague insofar as its paradigm (as both Mittel and Nannicelli assert) is specifically the nineteenth-century one, especially those books that were published, and also conceived and structured, as serials. Given more scope, we could say plenty about the sociology and economies of serial literature as it relates to the consumption of contemporary television, in its broadcast, box-set, or digital form. For the purposes of this essay, though, I will focus mainly on the aesthetics of serial television, in particular, how episode conclusions and cliff-hangers relate to a conception of the television text as 'novel'. We should note, however, that the sociology of both the large-scale novel and long-form television have a determining impact on their form and style. As Levine points out, the complex narrative structure in a show such as The Wire, distinct from the contained-episode narratives of most mainstream television dramas and feature films, 'is itself enabled by a serialized-episode-into-volume form that has a precise corollary in the Victorian novel'.

Seriality, then, shapes the structure and interpretation of the novel. As John Caughie has argued, serials such as The Wire or The Sopranos share with novels such as Dickens' Bleak House their sense of episodic narrative as an 'epistemology'. Caughie argues for long-form narrative television as a cognitive process of hypothesis testing and discovery, a formal process of reading and deducing through 
which 'connectedness and entanglements' (60) are revealed. Suspense plots and cliffhanger endings are in this sense not just mechanisms to maintain interest (and also, of course, consumption of the product, a factor to which I will return below), but use delay and suspended revelation to elicit broader epistemological questions of cause, effect, and connection.

We might understand this better with regard to the particular uses of serial suspense in some recent television, including The Killing. Caughie observes the ways in which the 2005 British Broadcasting Corporation (BBC) television adaptation of Bleak House makes skilful use, at climactic points, of movement across temporally consistent but physically disparate spaces - Tulkinghorn's offices, the Dedlock's country estate at Chester Wold, Krook's bottle shop - through the specifically filmic and televisual use of cross-cutting, also known as parallel editing. The associations of these editing patterns hint at possible but as yet unspoken interconnections and histories (Caughie 64). Episode two concludes with three wordless shots, linked only by extradiegetic sound: the lawyer Tulkinghorn, drinking wine; cut, via a graphic match, to the landlord Krook (the owner of significant love letters implicating, it is implied, 'a Lady') drinking gin; and finally to the quietly weeping and immobile Lady Dedlock, the third party caught between the machinations and mercenary intentions of these two men. The two men are linked by their shared knowledge and shared act of drinking, while the gendered structure of power within the narrative context is also economically marked by Lady Dedlock's mute, static appearance as an apparent end point and destination of the men's reflections.

Mittel's argument is that these formal effects characterize television narrative, in place, for example, of 'internal monologues or speeches articulating characters' deep thoughts' (431). If we believe Sergei Eisenstein, of course, D.W. Griffith's development of parallel editing was actually inspired by Dickens, and from one perspective, this technique economically presents the imagined 'simultaneity' of social action and event that, as Benedict Anderson famously observed, is a structural hallmark of the capitalistsociety novel in its numerous forms (25).

\section{WATCHING FORBRYDELSEN}

What is used momentarily in Bleak House becomes a defining aesthetic method in Forbrydelsen, where each of the 20 episodes ends with a climactic, frequently suspenseful and always wordless montage of its protagonists, alluding constantly to the interdependency of these dramatic agents across spatial boundaries. To return to Caughie's discussion of suspense and epistemology, what each cliff-hanger ending offers us is always more than just a mechanism for suspense, mainly because the suspense is based on a series of interdependent actions, the interdependency of which can only be interpreted and inferred by the viewer. Significantly, for a discussion which centres around the notionally high(er)-cultural connotations of the novel and the novelistic, these endings not only allude to the practices of serial publication but also rely on prototypical dynamics of melodrama: our own omniscience over the protagonist's restricted field of knowledge, the race against time, and the constant threat of events unfolding 'too late'. Yet, our filling in the gaps becomes in Forbrydelsen a means of identifying the impediments to justice within the broader urban stage, the impediments which both give the 
series its duration and map out the schisms and tensions that incrementally define its space of representation.

At the conclusion to episode six of Forbrydelsen, for instance, the montage moves between three spaces of action. In the first, Troels Hartmann, the aspiring mayoral candidate, leaves the set of a television debate where he has been pushed into defending his multiracial policies. One of Troels's youth leaders, Nanna's literature teacher Rama, a secularized Muslim, is a prime suspect in the murder case, but Troels refuses to suspend him or question his innocence. Troels is therefore positioned, thanks to the argument of his rival, Mayor Bremer, as a supporter of criminals. That Rama's possible implication in the murder was not noticed earlier - and in the intervening time Troels has been photographed shaking hands with him — was due to an as-yet unspecified political action, resulting in the removing of teacher information files. A knockon effect of this concealed information, and hence suspicion, is that Rama goes to Nanna's funeral, unsuspecting of his being targeted by Nanna's father, Theis, as the possible murderer of his daughter. Theis, who it is implied was once involved in violent gangland criminality, offers to drive Rama home. As Sarah Lund prepares to leave Copenhagen by aeroplane for her planned new home in Sweden, making a final phone call to her police colleague, Jan Meyer, she is able to work out the danger Rama has placed himself in. Lund therefore has the flight stopped and struggles to be let off, as we see Theis passing the designated turn for Rama's home and heading somewhere out of town. We are left in suspense about Rama's fate, but also, the reasons for Rama's implication in the murder; what piece in the puzzle do we not know yet?

Elsewhere, at the end of episode fourteen, we see three areas of action that have no obvious relation, but whose interdependency is hinted at by the editing. Hartmann, now the main suspect in the case, languishes in a holding cell because - for reasons of political profile - he would not disclose his whereabouts the night of the murder. A subsequent edit sees his two advisers - one of whom knows the truth and would not tell it-look at each other through a glass partition. Meanwhile, Sarah Lund has accidentally put herself in danger from another politician who we realise - at the same time she does - is implicated in another murder. But this other murder, we work out, was to cover up information, the concealment of which helps to implicate Hartmann in the other, central murder case. Discovering 'too late' that Lund is in danger, then, her partner Meyer rushes out of the police station, neatly moving through the two political animals at odds across the partition.

As the reader will remark, trying to put these down in words feels exhausting and convoluted. There is also an inevitable sense of overexplanation in the act of description. Of course, what I am really doing in the above paragraph is piecing together parts of narrative information, but also interpretations of this information. What the montage sequence actually gives us, here and in every other episode, is fleeting glimpses of space whose associations and interconnections, to follow Caughie, constitute an 'epistemology' of the urban setting, but only through the interventions of the viewer to deduce and make sense of them. Convolutedness, and also in turn a kind of melodramatic excess in the juxtaposition of simultaneous event, is a necessary element of the narrative form and sociopolitical meaning of the series. In the sequence from episode six, for instance, without actually telling us what to think, we deduce the extent to which 
the problems and possibilities of the modern multiracial city, and the varied political mileage to be derived from it, bind the fates of all involved in this part of the narrative.

Counter-intuitively, perhaps, the overcharged significance of these montage sequences, together with their resistance to linguistic description, brings them closer to the spirit of the nineteenth-century novel, albeit in a roundabout way, in terms of their recourse to melodramatic modes. What parallels the modern Danish capital may actually have with the London of Bleak House gives way here to the more immediate point that Forbrydelsen's Copenhagen is a textual construction along prior (melo) dramatic lines: Sveistrup has indeed said in a New Yorker interview that in writing Forbrydelsen he was 'more interested in myth ... I'm thinking more Biblical, I'm thinking a large story. It was more Charles Dickens than it was, What did they do in "Twin Peaks"?'(Collins, Danish 29). Dickens' aspiration to the theatrical form in his novels is suggested by the way many 'scenes' in his novel are figured as self-contained episodes, with a strong emphasis on dramatic peaks of action and revelation, often climaxing in 'visual' set pieces, such as the deaths of principal characters. Such connections between stage melodrama and the nineteenth-century novel have been made forcibly by Peter Brooks in The Melodramatic Imagination, especially in his emphasis on the 'tableau' as a key motif adapted by the novel from stage melodramas. Brooks describes the climactic stage tableau, where protagonists are effectively frozen in a form of wordless gesture, as 'a hyperbolic instance ... of a more extensive recourse to muteness': the point, that is, where words fail and meaning can only be realised through symbolic physical expression. 'In these gestures more than in the words were represented and made present the purest conflicts and issues' (61); they 'give the spectator the opportunity to see meanings represented, emotions and moral states rendered in clear visible signs' (62).

The allusions to tableau in the episode endings to Forbrydelsen make comparative sense in terms of the way they narrate both the difficulty of communication between its represented spaces and the dramatic and at the same time thematic impact of this difficulty, the obstacles to communication, spatial, temporal, and political, being both the subject of representation and the dramatic vehicle. This is a good example of the way the series' 'double storytelling' approach is something of a misnomer (or even, as I will suggest below, a disclaimer), as the generic elements of cliff-hanger and suspense cannot be separated from Forbrydelsen's efforts to represent modern social and political experiences. The analogy here between the nineteenth-century melodramatic mode and contemporary television is, notably, inflected and reconfigured according to historical and media-specific contexts. The gesture of the emerging bourgeois individual in Brooks' reading of the melodramatic, in the novels of Balzac and their contemporary stage plays, is perhaps less sustainable in the contexts of twenty-first-century postmodern, postindustrial urban topographies. Eugène Rastignac's exemplary melodramatic gesture at the conclusion to Balzac's Père Goriot, where from a panoramic viewpoint he challenges the city of Paris to a duel, might be an absurd or even camp gesture in the contemporary television serial. Forbrydelsen nevertheless rethinks the tableau, its frozen dramatic gesture, in terms more suited to the types of spatialization generated by globalization and modern communication technologies. If the stratifications of politics, power, and capital can no longer be located in one place, these find their modern televisual equivalent in the fragmented quality of parallel editing, where drama is located 
not just within individual action but through the conjunction of individual trajectories. Its ubiquity in long-form television drama is an indication of the way such devices have become chronotopes of the increasingly dispersed, massively populated and stratified, but also interdependent, modern city. At the same time, though, the mimetic inflections we might infer from such stylistic practices also occludes their basis in 'lower' modes (in this case, the melodramatic): a typical feature of Forbrydelsen, but also, as we will now see, of the novel adapted from it.

\section{READING THE KILLING}

For example, when we come to read The Killing, we see that it eschews the cliff-hanger structure. The novel is divided into 14 chapters, the first and the last essentially prologues and epilogues to the main body of the action. The temporal and dramatic economy of Forbrydelsen - in which each of the 20 episodes corresponds roughly to one day in the investigation - is changed then to 12 chapters of fluctuating length and coverage. What is most significant in this structural choice is its specific focus. Some earlier chapter endings perform the function of cueing expectation and possible avenues of investigation, though the focus of many endings is notably character oriented. In this instance, moments of complex interdependency are more embedded within the flow of chapter action than promoted to a form of episteme of time and place. The sequence from the end of episode fourteen to which I previously referred, for example, takes place in the middle of chapter eight. The previous chapter ends with Sarah Lund arguing with her son, while the conclusion to chapter eight itself has an exhausted Lund being told to rest by her boyfriend:

[Mark] thrust his feet deep into the footwell, locked his arms together [...]

"I know it's been difficult, Mark, but don't worry. I'll deal with it. Nothing's changed. We're still the same."

"It's not the same. You damn well know it."

"Mark - "

"I don't want to talk about this."

"Mark - "

"It's my life!" he yelled. "You don’t own me." (Hewson 434)

[Bengt] reached out and gently stroked the hair from her forehead [...]

She was staring at the blank TV. Hand reaching for the remote.

"Come to bed, Sarah. For God's sake, let it go." (Hewson 478)

The novel, in this way, frequently looks to subordinate action to a character-centred and psychological structure, placing the protagonist's thoughts and relationships central.

The novel also serves as a type of commentary on the television series, especially in terms of location. In this sense, the novelization attempts to bridge the transnational interpretive gap that opens up, increasingly in the era of globally exportable television, between a programme's original domestic audience and its dispersed global viewers. Spaces of the city which remain unexplained to television viewers not familiar with the politics of Copenhagen space - especially the working-class district of Vesterbro, which as home to the Birk Larsens underpins the series' interest in economic strata and mobility - are meticulously named and described in Hewson's novel. In some sense, though, 
this process of naming paradoxically effaces much of the spatial quality central to the television series' effect. Or rather, the condition of spatial interdependence as one that is conceived inductively, as per Caughie's reading of the nineteenth-century novel, is here reworked in a more omnisciently descriptive manner. This becomes most notable when Hewson looks to offer panoramic overviews:

Three politicians about to fight each other for the crown of Copenhagen, the capital city, a sprawling metropolis where more than a fifth of Denmark's five and a half million natives lived and worked, bickered and fought. Young and old, Danish-born and recent, sometimes half-welcome, immigrant. Honest and diligent, idle and corrupt. A city like any other. (12)

Beyond this passage's odd contradictions and the rather too precise detail, is the sense of an omniscient vision effectively mapped onto the narrative rather than inferred from it in its long-form development. From one point of view, such descriptive vistas are 'literary' in their endeavour to capture the urban totality in tones metaphorical and naturalistic: the allusion to the 'crown' of the city, the city itself captured as a teeming organism of varied peoples. At the same time, such passages take the effective form of 'establishing' sequences, taking their cue as much from cinema and television as from the novel form.

From one point of view, this suggests the reciprocal influence between screen narrative form and that of the novel within the era of convergence, a point underscored by The Killing's general mode of fragmented narrative 'scenes' that rarely exceed two pages in length. But arguably, this reciprocity is already well established within one genre - 'hard boiled' detective fiction - whose literary development and recognition is synchronous with the emergence and dominance of comparative screen fictions, many of them being adaptations of the same fiction - those movies generally identified as films noir (Luhr 4). In the case of The Killing, the narrative economy of the television series is refunctioned in the book in terms of a frequently laconic, tough style, especially at the start of scenes, one where verbs are surrendered to narrative expediency and action

Shining wood. Long slender leaded windows. Leather furniture. (12)

Four of them face to face across a plastic table. Plain facts. (46)

In Lund's room, coffee sitting on the desk, untouched, Theis and Pernille Birk Larssen listening. (90)

or one ready to throw out fleeting chunks of (received) urban wisdom, or acerbic character sketches, as follows:

A school was a world in miniature, riven with gossip and rumour. (59)

The church was plain and cold, the priest much the same. (98)

Such writing suggests the literary model is the detached, often derisive tone of Dashiel Hammett or even Raymond Chandler, whose description (in The Long Goodbye) of Los Angeles as 'a city no worse than others' (322) finds itself paraphrased, as seen above, in Hewson's novel. ${ }^{4}$ And yet, it is either an indication of the discursive seriousness now attending the detective novel, bringing it up out of its low, pulpy roots, or a sign on the part of The Killing to distinguish itself from pulp connotations, that such allusions 
are intermittent parts of a much broader and more varied set of literary signifying practices in the book. This intent, as I will conclude below, seems part of the varied ways that both novel and television series at once construct and disavow their cultural connotations.

One of Hewson's most obvious authorial interventions is the effort to represent subjectivity - what Ian Watt calls 'this minute-by-minute content of consciousness'(453) - through modes of narrative focalization and voice that are developmentally associated with the nineteenth-century novel. This effort to make subjectivity a more central focus of the novel is further marked by the tendency to conclude chapters from the perspective of individual agents within the drama. One effect here is to intercede in the blank, present tense flow of the television show and its apparently cool, procedural actions. Hence, one of Lund's characteristically wordless forensic examinations from the television series, where she inspects Nanna's room (episode four), is rendered in the novel in a combination of implied interior monologue and free indirect discourse:

Lund thought of herself at [Nanna's] age, an awkward, morose child. Her room more untidy than this. But different somehow [...] Here, she thought, Nana had created a place for preparation. A private dressing room from which she would emerge to enchant the world outside, entrance it with her beauty, her clothes, her sparkling and obvious intelligence.

All the things the teenage Sarah Lund lacked this girl possessed in abundance. A loving mother too.

And now she was dead (Hewson 123).

Such passages highlight the role of novelization not as redundant reproduction but as a form of interpretive adaptation and critical reading, as per Dudley Andrew's suggestion that adaptation is a form of hermeneutic, a work of 'appropriat [ing] meaning' that is at once 'a leap and a process' (97). Notably, the kind of 'leap' made here is to attribute to the novel as a medium that which, supposedly, the television serial does not have: in Mittel's words, 'internal monologues or speeches articulating characters' deep thoughts, [a sense] of deep character goals [and] transformations motivating the dramatic actions'.

Levine's riposte to Mittel is that such attributes are hardly necessary characteristics of the Dickensian novel to which Mittel specifically refers. Most subtly, she identifies the way that long-form television displays its affinities to the Dickensian novel precisely through its absence of clearly defined narrative point of view. Levine sees in The Wire's shift between the intimate and the panoramic an analogy for Bleak House's movement between Esther Summerson's first-person narration and that of the unidentified third-person narrator. From this perspective, the missing novelistic links of long-form television are not really missing at all; though it is notable that in Hewson's use of free indirect modes, we get an intimation of the oscillation between an omniscient narrative voice and the voice of a protagonist whose grasp of events, or even of his/ herself, remains partial and restricted. It is also significant that linguistic allusions to the hard-boiled detective genre, and specifically its use of first-person narration, are subsumed not just within a third-person narrative, but one which is distributed across The Killing's principal narrative agents, most prominently, Lund, Hartmann, and the Birk 
Larssens (and while Chandler's Philip Marlowe might wax lyrically about his native city, in Hewson's novel, only the impersonal narrator has this necessary detachment and privilege). In this sense, the form of The Killing, but also its scale (709 pages), is attentive to a mutually influencing concept of novel and television narrative that is extensive as much as intimate.

There is though another discursive agenda in Hewson's approach, as in trying to depict an emotional and psychological life for Lund, and more significantly, one interwoven with, and shaped by, the crimes she investigates; Hewson is being entirely consistent with what we might call the critical legitimation of the crime novel, via policemen such as Ian Rankin's John Rebus, or Henning Mankell's Kurt Wallander, whose emotional lives and perspectives are woven into the fabric of the tale. In taking on a piece of iconic Scandinavian crime narrative, Hewson is no doubt also familiar with Maj Sjöwal and Per Wahlöö's Martin Beck novels, the ten-volume, three hundredchapter Swedish procedural series often held to have introduced, besides a Balzacian sense of scale and vision, 'genuinely radical elements into what was at the time [considered] an unthreatening form' (Forshaw 17), novels in which systemic corruption was figured within the representation of everyday social realities and procedures. Just as Sjöwal and Wahlöö are often held to have established a decisive break with the 'golden age' tradition of 'country house' detective fiction (Beyer 144-145), the emphasis in Hewson's novel on the personal as political breaks with a tendency in millennial crime television - most notably CBS's Crime Scene Investigation (CSI) (2000-) - towards a type of 'forensic' television aesthetic: the reduction of bodies and evidence to DNA traces, bullet penetration tracks, and blood-splatter patterns (Scaggs 41). In terms of the reciprocal discursive influence of one text over another, the connotations of Hewson's novel feed back onto Forbrydelsen, segregating the multilayered serial from the more episodic format of a show like CSI.

Yet, the structural transitions within the novel that by reflection distance Forbrydelsen from a show like CSI also occlude the former's more problematic associations, its very status as a television show. Because it effaces the structure of seriality that is so prominent in the television series, The Killing downplays the inevitable way that serial television necessarily functions through the logic of the commodity. Those who sponsor or pay for the production of serial television drama depend upon its viewers' desire and anticipation being consistently maintained, something the cliff-hanger form of Forbrydelsen does remarkably well. Yet, while both Forbrydelsen and the BBC's Bleak House employ similar narrative structural effects, the discursive values of adaptation are very different here. Much discussion of the 'soap opera' format of the 2005 Bleak House has focused on the way it works to reconfigure the cultural status of Dickens' original novel, precisely by finding analogous methods of representing the novel's own serial origins (Kleinecke-Bates 114). Here, narrating Bleak House in thirty-minute cliff-hanger episodes represents Dickens through the prism of low culture, a process that both undercuts the high- or middlebrow connotations that often adhere, ahistorically, to his work (partly through the production of 'quality' or 'prestige' television or film adaptation) and rethinks the problematic discursive division of high- and low-cultural forms (Kleinecke-Bates ibid.). By contrast, in downplaying the serial structure of Forbrydelsen, Hewson's novel works in part to legitimize the narrative within middlebrow or quality 
terms: terms which, in this instance, disavow the commodity structure that largely defines it.

I do not mean here to hold Hewson's novel to account for somehow failing to adhere to Forbrydelsen's structural form, but there is clear analytical mileage in seeing how the later text incorporates or sometimes disavows the presumed discursive status of its televisual model as part of its own signifying process. The Killing's structure and style associate it with a more 'literary' type of detective novel, apparently freed from its associations with pulp commercialism and the industrial logic of serial production. As a novelistic work, it is not 'just' a forensic procedural, nor a melodrama, nor a cliff-hanger narrative, and in turn, by reflection, neither is the series on which the novel is based. Indeed, we find the same discursive disavowal of generic or low-cultural characteristics in the production strategies of Forbrydelsen, with Sveistrup claiming that the central crime narrative of the series was 'just an excuse for telling a lot of other stories' and producer Piv Bernth saying that the show is 'not just about finding the murderer' (both in Redvall, 173). As Redvall puts it, 'Audiences might primarily think of The Killing as an entertaining crime series ... but in the corporate storytelling of DR Fiction it is a series with several layers beneath the crime investigation, legitimizing it as a public service television product' (173).

The logic here is problematic but revealing in its suggestion that audiences may 'think' they're watching 'just' a crime show but are 'actually' watching something else. This says as much about the discomfort of acknowledging the effect of generic structures on audiences and producers, as it does what is actually happening in these series. Discursive efforts to 'legitimize' the narrative in The Killing gloss over some of the more mechanistic elements of the original series, some of which - notably, the cliff-hanger endings discussed above - give it its distinctive form and feeling (in fact, the show to which Forbrydelsen's time-determined structure owes most, even though it is not widely discussed, is Fox's $24(2001-10)$ ). Precisely because it is structured around an economy of time limitations and deadlines that preclude reflection, on the part both of the protagonists and the viewers, the television series constructs a machinic and determined vision of the city that actually restricts the development of 'character' or 'depth', in the psychological and emotional sense, we may have come to expect in contemporary 'cine-literary' media, the kind of developmental character space nevertheless exploited by Hewson's book. As an interpretation of the television series, then, legitimated through channels of publication and consumption, The Killing reveals a great deal about the discursive associations and values attributed to contemporary television fictions, but it also reveals how potentially misleading these associations can be.

\section{CONCLUSION}

As I've argued here, the novelization of The Killing is consistent with a discursive contemporary effort to legitimize televisual form with reference to the older medium of the novel. This makes sense in terms of the desire to distinguish such shows from other contemporary production, especially in terms of recent popular crime television. Surveying both series and novel is nevertheless a useful indicator of the limitations involved in viewing 'the novel' as a concept through purely medium-specific paradigms, or taking 
an ahistorical approach to conceptions of the novelistic more broadly. Analysing both the television series and the novel adapted from it provides a good example of the fluid and discursive nature of 'novelistic' narrative across different media.

\section{NOTES}

1 Two follow-up novels, The Killing II (2013) and The Killing III (2014), again written by Hewson, were published on the back of the next two series of Forbrydelsen, produced in 2009 and 2012 and screened in the United Kingdom in 2011 and 2012, respectively. Purely for reasons of space, I am unable to look at these novels in the present essay.

${ }^{2}$ In the rest of this essay, I will use The Killing to refer specifically to the novelization, and Forbrydelsen in reference to the television series.

${ }^{3}$ During my regular visits to Manchester Piccadilly station, for example, I have recently seen prominent platform posters for the two latest novels by Jo Nesbø, as well as the third novel in Hewson's Killing series.

${ }^{4}$ My thanks to Jim Peacock for this observation.

\section{REFERENCES}

Anderson, Benedict. Imagined Communities. London and New York: Verso, 1991.

Andrew, Dudley. Concepts in Film Theory. Oxford, New York, Toronto and Melbourne: Oxford University Press, 1984.

Archer, Neil. "The Girl with the Dragon Tattoo (2009/2011) and the New 'European Cinema."” Film Criticism 37.2 (2012-2013): 2-21.

Baetens, Jan. "From Screen to Text: Novelization, the Hidden Continent." The Cambridge Companion to Literature on Screen. Eds. Deborah Cartmell and Imelda Whelehan. Cambridge: Cambridge University Press, 2007: 226-38.

Beyer, Charlotte. "DDeath of the Author': Maj Sjöwal and Per Wahlöö's Police Procedurals." Cross-Cultural Connections in Crime Fictions. Eds. Vivien Miller and Helen Oakley. Basingstoke and New York: Palgrave Macmillan, 2012: 141-59.

Bolter, Jay David and Richard Grusin. Remediation: Understanding New Media. Cambridge, MA: MIT Press, 2000.

Brooks, Peter. The Melodramatic Imagination: Balzac, Henry James, Melodrama and the Mode of Excess. New Haven and London: Yale University Press, 1976.

Caughie, John. "Television and Serial Fictions." The Cambridge Companion to Popular Fiction. Eds. David Glover and Scott McCracken. Cambridge: Cambridge University Press, 2012: 50-67.

Chandler, Raymond. The Long Goodbye. London: Penguin, 2005.

Collins, Jim. Bring on the Books for Everybody: How Literary Culture Became Popular Culture. Durham: Duke University Press, 2010.

Collins, Lauren. "The Danish Postmodern." The New Yorker Jan. 2013: 22-30.

Eisenstein, Sergei. "Dickens, Griffith and the Film Today." Film Form: Essays in Film Theory. Trans. Ed. Jay Leda. San Diego, CA: Harcourt Brace Jovanovich, 1977: 195-255.

Ellis, John. "The Literary Adaptation.” Screen 23.1 (1982): 3-5.

Forshaw, Barry. Death in a Cold Climate: A Guide to Scandinavian Crime Fiction. Basingstoke and New York: Palgrave Macmillan, 2012.

Hewson, David. The Killing. Basingstoke and Oxford: Pan Macmillan, 2012.

Jenkins, Henry. Convergence Culture: Where Old and New Media Collide. New York and London: New York University Press, 2006.

Kleinecke-Bates, Iris. "Historicizing the Classic Novel Adaptation: Bleak House (2005) and British Television Contexts." Adaptation in Contemporary Culture: Textual Infidelities. Ed. Rachel Carroll. London and New York: Continuum, 2009: 111-22.

Levine, Caroline. "From Genre to Form: A Response to Jason Mittell on The Wire." electronicbookreview.com. 2011. 9 Apr. 2014. http://www.electronicbookreview.com/thread/firstperson/ serialrip. 
Luhr, William. Raymond Chandler and Film. Tallahassee, FL: Florida State University Press, 1991.

Mittel, Jason. "All in the Game: The Wire, Serial Storytelling and Procedural Logic." Third Person: Authoring and Exploring Vast Narratives. Eds. Pat Harrigan and Noah Wardrip-Fruin. Cambridge and London: MIT Press, 2009: 429-38.

Murray, Simone. "Materializing Adaptation Theory: The Adaptation Industry." Literature/Film Quarterly 36.1 (2008): $4-20$.

Nannicelli, Ted. "It's All Connected: Televisual Narrative Complexity." The Wire: Urban Decay and American Television. Eds. Tiffany Porter and C.W. Marshall. London and New York: Continuum, 2009: 190-202.

Redvall, Eva Novrup. Writing and Producing Television Drama in Denmark: From The Kingdom to The Killing. Basingstoke and New York: Palgrave Macmillan, 2013.

Scaggs, John. Crime Fiction. London and New York: Routledge, 2005.

Watt, Ian. "From The Rise of the Novel: Studies in Defoe, Richardson, and Fielding." Theory of the Novel: A Historical Approach. Ed. Michael McKeon. Baltimore and London: Johns Hopkins University Press, 2000: 441-66. 